\title{
USE OF MOBILE-APP FOR OLDER PEOPLE WITH CHRONIC DISEASES TO COPE WITH THE COVID-19 PANDEMIC: A LITERATURE REVIEW
}

\author{
Ni Luh Putu Dian Yunita Sari ${ }^{{ }^{*} \text {, I Kadek Prastikanala }}{ }^{2}$ \\ 1. Bachelor of Nursing Study Program, Stikes Bina Usada Bali, Indonesia \\ 2. Bachelor of Nursing Study Program, Stikes Bina Usada Bali, Indonesia \\ *Correspondence: Ni Luh Putu Dian Yunita Sari | Stikes Bina Usada Bali | dian.yunita@binausadabali.ac.id
}

\begin{abstract}
Introduction: The older people with chronic diseases are one of the populations that have a susceptibility to COVID19. The community-based program that help older people manage their lifestyle was postponed due to avoiding crowds and physical contacts. This literature review aims to describe a mobile-app for the older people with chronic diseases and its benefits. This literature review aims to describe a mobile-app for the older people with chronic diseases and its benefits.

Method: The method used in this study is a literature review. This study is analyzed by selecting some literature that is relevant to the purpose of writing in order to obtain new conclusions. Online databases used are ProQuest, Pubmed and Science Direct starting from 2019 to 2021. The keywords used to sort articles in this study are: 1) older people, 2) mobile app, 3) COVID-19.

Results: There was ten selected articles that analyzed. This literature review resulted in three main themes in the use of mobile-apps for the older people with chronic diseases, namely (1) monitoring of chronic diseases and COVID-19, (2) management of chronic diseases and COVID-19, and (3) the perspective of older people caregivers. The implication for nursing services is that nurses can disseminate information and provide interventions by minimizing physical contact. In addition, these results also have implications for the scope of nursing education, namely adding reference material for studies in health information systems courses.

Conclusion: These results can be used as a basis for creating mobile-app-based educational media, monitoring, and self-management of chronic diseases for the older people and their caregivers.
\end{abstract}

Keywords: COVID-19, Aged, Technology, Chronic Disease.

Received November 18, 2021; Accepted December 30, 2021

\section{INTRODUCTION}

The older people are one of the populations that have a susceptibility to COVID-19 disease. This is because the older people have experienced some setbacks in physiological functions as a result of the aging process (Miller, 2015). The interaction between aging factors and unhealthy lifestyles in the past resulted in the older people experiencing chronic diseases. There are two most chronic diseases experienced by the older people in Indonesia, namely diabetes mellitus and hypertension. Indonesian basic health research data in 2018 states that the highest prevalence of hypertension in people aged 55-64 years is 55,2\% (Health Ministry of Indonesia, 2019a). In addition, the highest prevalence of diabetes mellitus in 2018 was also experienced by the older people, namely 15,9\% (Health Ministry of Indonesia, 2019b). This figure shows that the main health problems experienced by the older people before the pandemic were noncommunicable diseases.

The shift in older people health problems is currently occurring from non-communicable diseases to infectious diseases. However, the worse is that two health problems occur at the same time and have a poor prognosis. Health Ministry of Indonesia (2020) stated that the mortality rate due to COVID-19 occurred mostly in the age group of around 60 years and over. Most deaths occurred in the age group 80 years and over, with the percentage reaching $21,9 \%$. In addition, based on data collected by the COVID-19 Task Force, 1,488 COVID-19 patients were recorded to have co-morbidities. The largest percentage of comorbidities is hypertension, which is $50,5 \%$, followed by diabetes mellitus, which is $34,5 \%$ (Health Ministry of Indonesia, 2020a).

The interaction of non-communicable diseases and communicable diseases experienced by the older people in Indonesia is a serious health problem today. Management and lifestyle modifications for hypertension and diabetes mellitus have been carried out by the Indonesian government before the 
pandemic. The program being run is a community-based program called Posyandu Lansia (Sari, Sumarwati, \& Sutrisna, 2018). However, this activity was postponed due to avoiding crowds and physical contacts (Health Ministry of Indonesia, 2020c). Currently, community-based activities are in a vacuum and older people people with chronic diseases manage themselves in their own homes.

Self-management of the older people with hypertension and diabetes mellitus at home requires support from family and nurses. The current gap is that nurses must limit their interaction with the older people, but must maintain the health of the older people with chronic diseases. One solution that can bridge this gap is the use of technology. Jin, et al. (2019) mentioned that internet accessibility can significantly improve hypertension self-management and also reduce disparities in older people in China who live in rural and urban areas. Other than that, Quinn, et al. (2019) mentioned that digital applications provide opportunities for older people caregivers with hypertension to receive information and be involved in hypertension selfmanagement. Therefore, the use of technology to support self-management of the older people with chronic diseases is very potential.

The use of technology in the scope of gerontic is known as gerontechnology. Gerontechnology is an interdisciplinary academic and professional field that combines gerontology and technology with the aim of improving prevention and treatment measures and improving the quality of life of the older people (Creber, Hickey, \& Maurer, 2016). In addition, there is one relevant nursing model to represent the current condition is Roy's adaptation model. This model explains that there are two types of coping to defend themselves against stressors, namely regulatory and effector coping. Coping regulator emphasizes physiological needs while cognator is a coping mechanism that involves cognitive and emotional. These two types of coping form the basis for a person to be able to undergo the adaptation process in dealing with stressors (Alligood, 2014).

Optimization of coping regulators and cognators is needed to adapt to the stressors caused by the COVID-19 pandemic. Technology is the answer to the gaps that occur and the urgency of the needs of the older people with chronic diseases today. Technology is able to become an intermediary for service providers and recipients by minimizing contact. Further empirical studies are related to the right type of technology to answer this challenge. This literature review aims to describe a mobile-app for the older people with chronic diseases and its benefits for disease self-management.

\section{METHOD}

The method used in this study is a literature review. This study is analyzed by selecting some literature that is relevant to the purpose of writing in order to obtain new conclusions. Online databases used are ProQuest, Pubmed and Science Direct starting from 2019 to 2021. This year is used because the Covid-19 pandemic has only occurred in this year. The keywords used to sort articles in this study are: 1) Older People, 2) Mobile App, 3) Covid-19. There are ten articles selected after being cut off the duplication articles. 


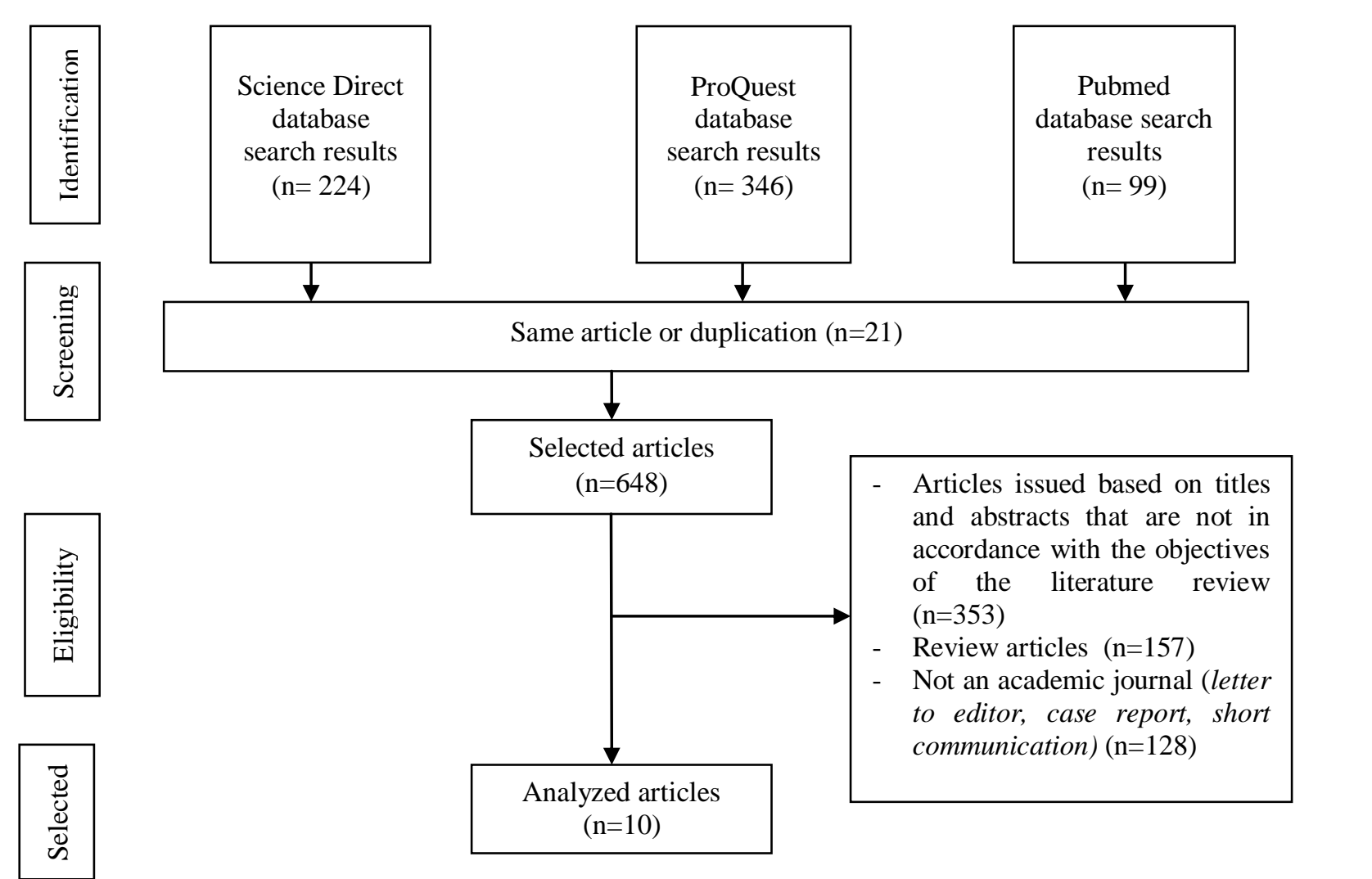

Figure 1. Article Selection Flow

\section{RESULTS}

The following are the results of the analysis of the ten articles selected in this literature review. There were three themes obtained, namely monitoring of chronic diseases and COVID-19, management of chronic diseases and COVID-19, as well as the perspective of older people caregivers.

Table 1. Detailed Description of Selected Articles in The Study

\begin{tabular}{clll}
\hline No & \multicolumn{1}{c}{ Articles' Title } & \multicolumn{1}{c}{ Result Research } \\
\hline 1 & $\begin{array}{l}\text { A digital mobile community app } \\
\text { for caregivers in Singapore: }\end{array}$ & $\begin{array}{l}\text { The feedback mobile app called Caregivers'. This app features are } \\
\text { predevelopment and usability } \\
\text { study }\end{array}$ & $\begin{array}{l}\text { discussions with a marketplace, care groups to hold private } \\
\text { feature. In general, caregivers like this application because it can } \\
\text { improve the quality of life. }\end{array}$
\end{tabular}

2 COVIDApp as an innovative strategy for the management and follow-up of covid-19 cases in long-term care facilities in catalonia: implementation study

3 e-CoVig: A novel mHealth system for remote monitoring of symptoms in COVID-19

4 Evaluation of the usability and acceptability of the InnoWell platform as rated by older adults: Survey study
COVIDApp can detect and monitor suspected cases and limit the risk of spreading the virus for 4 weeks.

The e-CoVig provides a set of functionalities for reporting symptoms, vital signs, and other clinical data. This application is dessigned to transmit the heart rate, $\mathrm{SpO} 2$, body temperature, respiration, and cough.

The usability scores of InnoWell Platform was suboptimal. Easy to use, the comprehensive of the assessment tools, and the ability to track progress over time were favored features of the InnoWell Platform. 
$5 \quad$ A pilot randomized controlled trial of a group intervention via Zoom to relieve loneliness and depressive symptoms among older persons during the COVID-19 outbreak

Mindfulness-based online intervention on mental health and quality of life among COVID-19 patients in China: An intervention design

Older adults can successfully monitor symptoms using an inclusively designed mobile application

Using a mobile health app to improve patients' adherence to hypertension treatment: A nonrandomized clinical trial

\begin{abstract}
The results showed a significant improvement in the intervention group in terms of both loneliness and depressive symptoms, compared with the control group. This intervention presents a relatively simple and effective technique that can be efficiently utilized to support older adults.
\end{abstract}

The efficacy and potential mechanisms of MLWC interventions in improving the quality of life of COVID-19 survivors are expected to be reported. This finding is expected to be a new innovation to improve the psychological function of COVID-19 survivors in difficult times.

There was no missing data, usability scores were high and not associated with age.

For 12 weeks, the experimental group had an increase adherence of hypertension medication. Another result showed that user experience were substantially positive and indicate that the participants in the experimental group had a satisfactory perception of the app.

9 Assessing acceptability and patient experience of a behavioral lifestyle intervention using fitbit technology in older adults to manage type 2 diabetes amid COVID-19 pandemic : A focus group study

10 Mobile health assessments of geriatric elements in older patients with atrial fibrillation : The Mobile SAGE-AF Study (M-SAGE)
The results of the thematic analysis showed that there was an increase in health knowledge, an increase in diabetes selfmanagement and an increase in quality of life after using fitness technology (Fitbit ( $)$ ).

The use of The Mobile SAGE-AF reported that within 1 month of completing a geriatric assessment $75 \%$ and completing a 6 -minute walk test a total of $63 \%$.

\section{DISCUSSION}

\section{Monitoring Chronic Disease and COVID-19}

Monitoring clinical symptoms in chronic diseases of the older people and COVID-19 is very important. However, public health nurses do not allow direct monitoring during this pandemic. This relates to the limitation of physical contact in an effort to reduce the risk of transmission. Therefore, the use of technology, especially mobile-apps, is a strategic solution to be implemented in monitoring older people diseases.

There are several articles in this literature review which stated that the use of mobile-apps is able to monitor chronic diseases and COVID-19. Lamonica et al. (2021) created an application called InnoWell designed for the older people. The results obtained are that this application is well received in the older people, easy to use, and comprehensive. Other than that, Turchioe et al. (2020) also mentioned that the mobile-app is effectively used to monitor disease symptoms, which are characterized by the absence of missing data and relatively high usage scores. Trymbulak et al. (2020) designed an application for the older people with atrial fibrillation called M-SAGE. The display of this application can be seen in Figure 1. This application is specifically intended to monitor the health condition of older people clients with heart disease who are declared successful with a relatively high level of use of this application. 


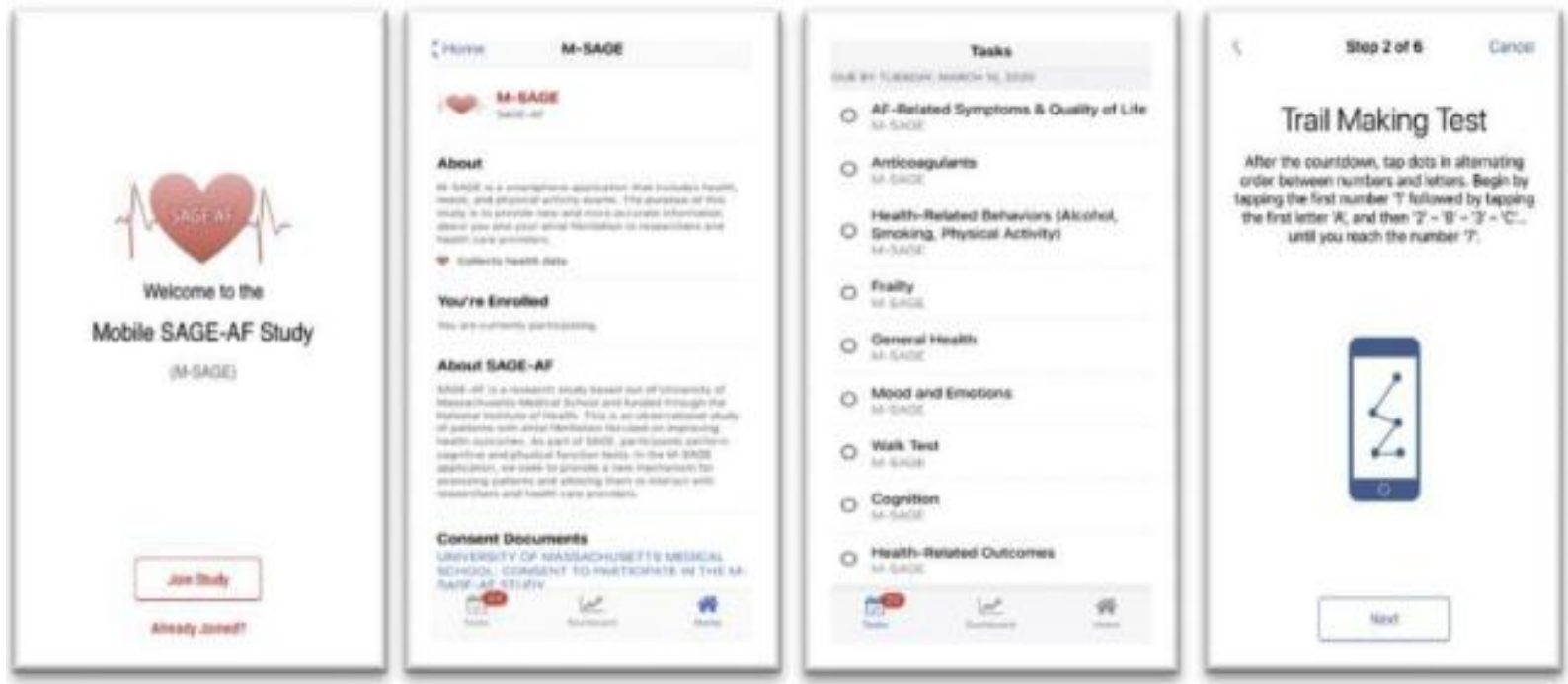

Figure 2. M-SAGE Application (Trymbulak et al., 2020)

In addition to chronic disease monitoring, the mobile-app is also used to monitor COVID-19 disease. Echeverr et al. (2020) stated that a mobile-app called COVIDApp managed to monitor COVID-19 cases and reduce transmission within four weeks. Raposo et al. (2021) also researching related to COVID-19 disease monitoring by developing a mobile-app called e-CoVig. The display of this application can be seen in Figure 2. The results presented in this study are that there are several features available for independent monitoring of COVID-19 disease, namely signs and symptoms, vital signs, and some other clinical data.

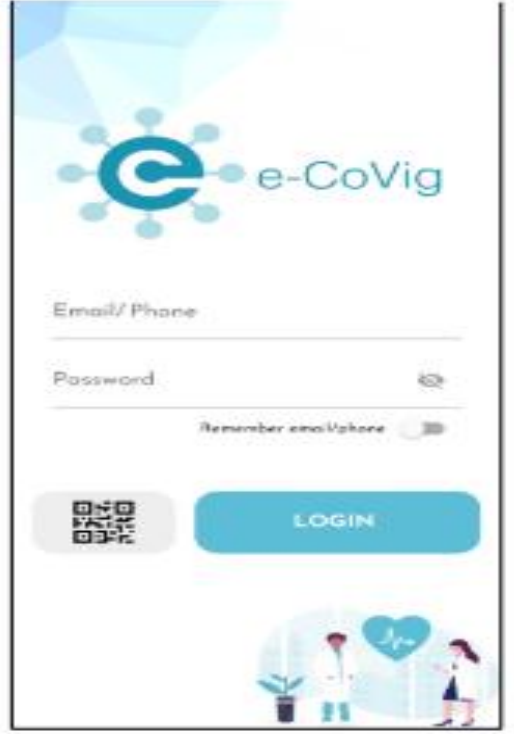

(a) Login sereen

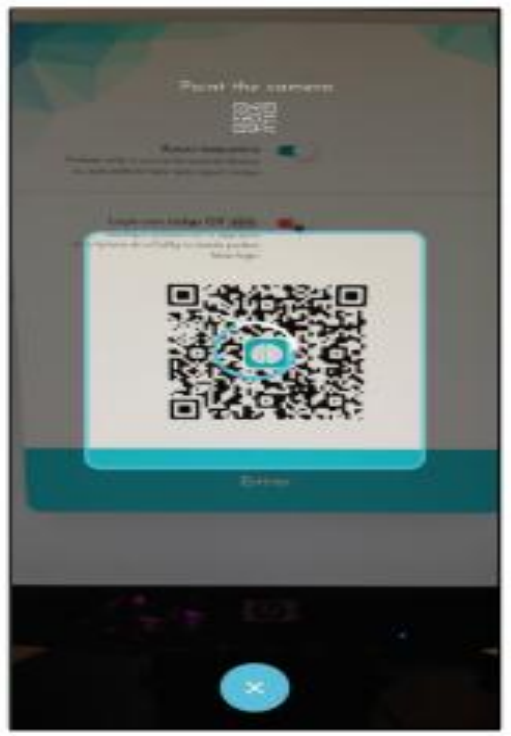

(b) QR code scan

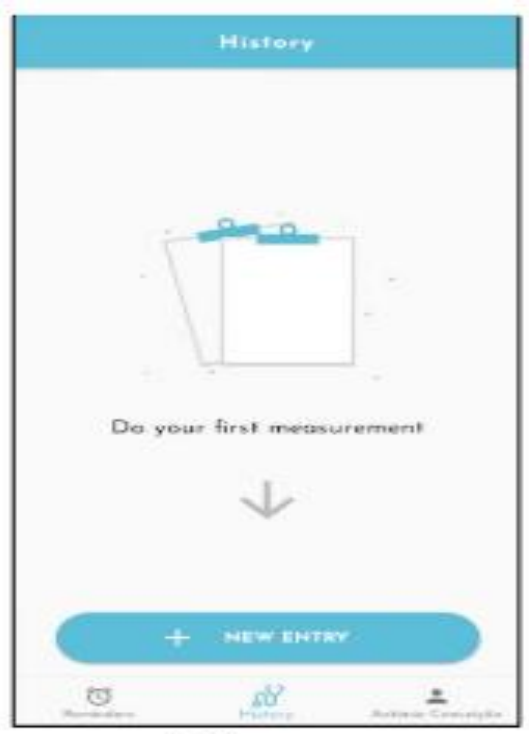

(c) Home seroen

Figure 3. E-CoVig Mobile Application (Raposo et al., 2021)

The results of this analysis are in line with several studies supporting the monitoring of chronic diseases of the older people during the COVID-19 pandemic. Telemonitoring is one of the most frequently performed interventions next to the use of mobile-apps. Mattioli, Cossarizza, and Boriani (2020) mention that telemedicine plays an important role in self-monitoring efforts for the older people with heart problems. Moreover, Scheibe, Lang, and Druschke (2021) also mention that telemonitoring in the form of an application helps the older people in self-care and disease monitoring, as well as increasing feelings of security. So, the use of technology during this pandemic is very relevant given to monitor the health of the older people who suffer from chronic diseases. 


\section{Management of Chronic Disease and COVID-19}

Self-management for the older people with chronic diseases is also very important. Lestari and Isnaini (2018) stated that there is a significant positive effect between self-management and systolic blood pressure ( $\mathrm{p}$ value $=0.000)$ and diastolic $(\mathrm{p}$ value $=0.034)$ in the older people with hypertension. Other than that, Rusdiana, Savira and Amelia (2018) mention that self-management-based interventions for people with diabetes had a significant effect on decreasing Hbalc values. So, self-management is an essential intervention that must be carried out by the older people with chronic diseases.

Management of chronic diseases of the older people before the pandemic was optimized through Pos Pelayanan Terpadu (Posbindu) program. The older people group carries out several activities in groups, including physical exercise, health education, medication management, nutrition management, and stress management (Siregar \& Wahyudi, 2018). However, during the pandemic this group activity cannot be done. Older people self-management during the pandemic is divided into seven interventions according to Rahman and Lassi (2021), namely strictly maintaining health protocols, managing a balanced diet, doing physical activities, doing favorite hobbies, doing spiritual activities, getting enough sleep (seven to eight hours per night), and communicating with friends or family via telephone. This concept is also supported by Quinn, Davies, and Hadjiconstantinou (2020) which stated that virtual communication and consultation has positive social and psychological implications for patients. So, the use of technology is very relevant in carrying out self-management of the older people during a pandemic.

There are several articles in this literature review which stated that the use of mobile-apps can help selfmanagement of patients with chronic disease. Shapira et al. (2021) mentioned that group intervention using zoom meeting media was able to reduce symptoms of depression in the older people during the COVID-19 pandemic. This result is also supported by $\mathrm{Si}$ et al. (2021) which stated that mindfulness therapy with online media can improve the quality of life of a person with COVID-19. Other than that,Volpi et al. (2021) mentioned that the mobile health application can improve medication adherence in hypertension patients. Jiwani et al. (2021) mentioned that there was an increase in health knowledge, an increase in diabetes self-management and an increase in quality of life after using fitness technology (FitbitO). So, chronic disease self-management interventions with mobile-apps are very efficient during a pandemic.

\section{Perspective of Elderly Caregivers}

The results of the analysis in this literature review state that older people caregivers feel the benefits of the mobile-app. Lwin, Sheldenkar, and Panchapakesan (2021) mentions that feedback mobile apps called "Caregivers" are used to hold private discussions with friends or other app users. In general, older people caregivers like this application because it can improve the quality of life. Ferré-grau et al. (2020) mentioned that smartphone applications have the potential to reduce the burden of caregivers and improve mental health. In addition, Ghahramani and Wang (2021) state that mobile app impact the capabilities and skills of caregivers take control of caregivers over their responsibilities and the decisions they make for their care receivers. So, mobile-apps are stated as media that can improve the quality of life, increase the ability of caregivers to care for the older people, and reduce the burden of caregivers.

The older people need a family to carry out self-management during a pandemic. Family support is in line with the theory of Family Center Nursing (FCN) which emphasizes that the family is the main place to learn about health and as a place to give and receive care throughout the life of all family members (Friedman, Bowden, \& Jones, 2003). This is also in line with research conducted by Li et al. (2021) which stated that the family is the biggest support system for the older people. In addition, this study also stated that resilience has a positive relationship with mental health and the support system can be a buffer in reducing things that trigger lower resilience during a pandemic. One of the things that can trigger lower resilience is the burden on the caregivers. Cravello et al. (2021) stated that family-based interventions can reduce the burden scale for caregivers of older people people with dementia. Thus, family-based interventions supported by the use of technology are needed during a pandemic for the older people.

\section{CONCLUSION}

This literature review resulted in three main themes in the use of mobile-apps for the older people with chronic diseases, namely (1) monitoring of chronic diseases and COVID-19, (2) management of chronic 
diseases and COVID-19, and (3) the perspective of older people caregivers. The implication for nursing services is that nurses can disseminate information and provide interventions by minimizing physical contact. In addition, these results also have implications for the scope of nursing education, namely adding reference material for studies in health information systems courses. These results can be used as a basis for creating mobile-app-based educational media, monitoring, and self-management of chronic diseases for the older people and their caregivers.

\section{ACKNOWLEDGEMENT}

The researcher thanks Stikes Bina Usada Bali for facilitating online databases in the preparation of this article. Both authors have the same role and there is no conflict of interest in the preparation of the article.

\section{REFERENCE}

Alligood, M. R. (2014). Nursing theorists and their work. Nursing Theorists and Their Work (8th edn). https://doi.org/10.5172/conu.2007.24.1.106a.

Cravello, L., Martini, E., Viti, N., Campanello, C., Assogna, F., \& Perotta, D. (2021). Effectiveness of a family support intervention on caregiving burden in family of older people patients With cognitive decline after the COVID-19 lockdown. Frontiers in Psychiatry, 12(March), 1-8. https://doi.org/10.3389/fpsyt.2021.590104.

Creber, R. M. M., Hickey, K. T., \& Maurer, M. S. (2016). Gerontechnologies for older patients with heart failure: What is the role of smartphones, tablets, and remote monitoring devices in improving symptom monitoring and self-care management? Current Cardiovascular Risk Reports, 10(30), 1-8. https://doi.org/10.1007/s12170-016-0511-8.

Ferré-grau, C., Raigal-aran, L., Lorca-cabrera, J., Ferré-bergadá, M., Lleixà-fortuño, M., Lluch-canut, M. T., \& Albacar-riobóo, N. (2020). A multi-centre, randomized, 3-month study to evaluate the efficacy of a smartphone app to increase caregiver's positive mental health. BMC Public Health, 19(888), 1-5. https://doi.org/https://doi.org/10.1186/s12889-019-7264-5.

Friedman, M.M., Bowden \& Jones. (2003). Family nursing: Research, theory, and practice (5 ${ }^{\text {th }}$ ed). Connecticut: Appleton \& Lange.

Ghahramani, F., \& Wang, J. (2021). Intention to adopt mHealth apps among informal caregivers: Crosssectional study. JMIR Mhealth and Uhealth, 9(3), 2-16. https://doi.org/10.2196/24755.

Health Ministry of Indonesia. (2019a). Hipertensi penyakit paling banyak diidap masyarakat. Health Ministry of Indonesia. Retrieved from https://www.kemkes.go.id/article/view/19051700002/hipertensipenyakit-paling-banyak-diidap-masyarakat.html.

Health Ministry of Indonesia. (2019b). Infodatin: Hari diabetes sedunia tahun 2018. Jakarta: Health Ministry of Indonesia. Retrieved from https://www.kemkes.go.id/article/view/19051700002/hipertensipenyakit-paling-banyak-diidap-masyarakat.html.

Health Ministry of Indonesia. (2020a). 13,2 persen pasien covid-19 yang meninggal memiliki penyakit hipertensi. Jakarta: Health Ministry of Indonesia. Retrieved from https://www.kemkes.go.id/article/view/20101400002/13-2-persen-pasien-covid-19-yang-meninggalmemiliki-penyakit-hipertensi.html.

Health Ministry of Indonesia. (2020b). Pasien positif corona meninggal dominan lansia. Jakarta: Health Ministry of Indonesia. Retrieved from https://www.kemkes.go.id/article/view/20042700001/pasienpositif-corona-meninggal-dominan-lansia.html.

Health Ministry of Indonesia. (2020c). Pedoman pencegahan dan pengendalian coronavirus disease (COVID-19). Jakarta: Direktorat Jenderal Pencegahan dan Pengendalian Penyakit Kemenkes RI.

Jin, Y., Jing, M., Zhang, L., Song, S., \& Ma, X. (2019). Internet access and hypertension management among the older people population: A nationally representative cross-sectional survey in China. Journal of Medical Internet Research, 21(1), 1-11. https://doi.org/10.2196/11280.

Jiwani, R., Dennis, B., Bess, C., Monk, S., Meyer, K., Wang, J., \& Espinoza, S. (2021). Assessing acceptability and patient experience of a behavioral lifestyle intervention using fi tbit technology in older adults to manage type 2 diabetes amid COVID-19 pandemic: A focus group study. Geriatric Nursing, 42(1), 57-64. https://doi.org/10.1016/j.gerinurse.2020.11.007.

Lamonica, H. M., Roberts, A. E., Davenport, T. A., Hons, B. A., \& Hickie, I. B. (2021). Evaluation of the 
usability and acceptability of the InnoWell platform as rated by older adults: Survey study. JMIR Aging, 4(2), 1-14. https://doi.org/10.2196/25928.

Lestari, I. G., \& Isnaini, N. (2018). Pengaruh self management terhadap tekanan darah lansia yang mengalami hipertensi. Indonesian Journal for Health Sciences, 2(1), 7-18. https://doi.org/https://doi.org/10.47679/ib.202167.

Li, F., Luo, S., Mu, W., Li, Y., Ye, L., Zheng, X., ... Chen, X. (2021). Effects of sources of social support and resilience on the mental health of different age groups during the COVID-19 pandemic. BMC Psychiatry, 21(16), 1-14.

Lwin, M. O., Sheldenkar, A., \& Panchapakesan, C. (2021). A digital mobile community app for caregivers in Singapore: Predevelopment and usability study. JMIR NURSING, 4(2), 1-13. https://doi.org/10.2196/25679.

Mattioli, A. V., Cossarizza, A., \& Boriani, G. (2020). COVID-19 pandemic: Usefulness of telemedicine in management of arrhythmias in older people people. Journal of Geriatric Cardiology, 593-596. https://doi.org/10.11909/j.issn.1671-5411.2020.09.010.

Miller, C. A. (2015). Nursing for welness in older adult: theory and practice (6th ed.). Philadelphia: Lippincott Williams \& Wilkins.

Quinn, C. C., Staub, S., Barr, E., \& Gruber-baldini, A. (2019). Mobile support for older adults and their caregivers: Dyad usability study. JMIR Aging, 2(1), 1-10. https://doi.org/10.2196/12276.

Quinn, L. M., Davies, M. J., \& Hadjiconstantinou, M. (2020). Virtual consultations and the role of technology during the COVID-19 pandemic for people with type 2 diabetes The UK perspective. Journal of Medical Internet Research, 22(8), 1-9. https://doi.org/10.2196/21609.

Rahman, M. S., \& Lassi, Z. S. (2021). Self-management for older people during the COVID-19 pandemic. Bangladesh Journal of Medical Science, 20(03), 694-695. https://doi.org/10.5770/chj.23.443.7.

Raposo, A., Marques, L., Correia, R., Melo, F., Valente, J., Pereira, T., ... Plácido, H. (2021). e-CoVig: A novel mHealth system for remote monitoring of symptoms in COVID-19. Sensors, 2, 1-19. https://doi.org/https://doi.org/10.3390/s21103397.

Rusdiana, Savira, M., \& Amelia, R. (2018). The effect of diabetes self-management education on Hba1c level and fasting blood sugar in type 2 diabetes mellitus patients in primary health care in Binjai City of North Sumatera, Indonesia. Journal of Medical Sciences, 6(4), 715-718. https://doi.org/10.3889/oamjms.2018.169.

Sari, Y., Sumarwati, M., \& Sutrisna, E. (2018). Pemberdayaan kader posyandu lansia untuk pencegahan hipertensi dan komplikasinya di purwokerto. Jurnal Pengabdian Pada Masyarakat, 3(1), 27-34. https://doi.org/10.30653/002.201831.49.

Scheibe, M., Lang, C., \& Druschke, D. (2021). Independent use of a home-based telemonitoring app by older patients with multimorbidity and mild cognitive impairment: Qualitative study. JMIR Human Factors, 8(3), 1-16. https://doi.org/10.2196/27156.

Shapira, S., Yeshua-katz, D., Cohn-schwartz, E., Aharonson-daniel, L., Sarid, O., \& Clarfield, A. M. (2021). A pilot randomized controlled trial of a group intervention via Zoom to relieve loneliness and depressive symptoms among older persons during the COVID-19 outbreak. Internet Interventions Journal, 24(2021), 1-6. https://doi.org/https://doi.org/10.1016/j.invent.2021.100368.

Si, M. Y., Xiao, W. J., Pan, C., Wang, H., Huang, Y. M., Lian, J., ... Yang, W. Z. (2021). Mindfulnessbased online intervention on mental health and quality of life among COVID - 19 patients in China: An intervention design. Infectious Diseases of Poverty, 10(69), 1-10. https://doi.org/10.1186/s40249-02100836-1.

Siregar, T., \& Wahyudi, C. T. (2018). IbM kelompok lansia penderita diabetes melitus (DM) di wilayah kerja Puskesmas Limo Kota Depok Jawa Barat. Jurnal Pengabdian Kepada Mas, 2(2), 93-104. https://doi.org/https://doi.org/10.20956/pa.v2i2.2987.

Trymbulak, K., Ding, E., Marino, F., Wang, Z., Saczynski, J. S., Netter, F. H., \& Haven, N. (2020). Mobile health assessments of geriatric elements in older patients with atrial fi brillation : The Mobile SAGEAF Study (M-SAGE). Cardiovascular Digital Health Journal, 1(3), 123-129. https://doi.org/10.1016/j.cvdhj.2020.11.002.

Turchioe, M. R., Grossman, L. V, Baik, D., Lee, C. S., Maurer, M. S., Goyal, P., \& Safford, M. M. (2020). Older adults can successfully monitor symptoms using an inclusively designed mobile aplication. 


\section{Jurnal Mitra Kesehatan (JMK)}

DOI: $10.47522 /$ jmk.v1iIAHSC.114

Journal of American Geriatrics Society, 00(00), 1-6. https://doi.org/10.1111/jgs.16403.

Volpi, S. S., Biduski, D., Bellei, E. A., Te, D., Mccleary, L., Luisa, A., ... Marchi, B. De. (2021). Using a mobile health app to improve patients adherence to hypertension treatment: A non-randomized clinical trial. PeerJ, 1-17. https://doi.org/10.7717/peerj.11491. 